\title{
Konsep Pendidikan Karakter Pada Sekolah Inklusi Tingkat Usia Dasar
}

\author{
Rina Rahmi ${ }^{1}$, Aswatun Hasanah ${ }^{2}$, Septika Laily Anti ${ }^{3}$ \\ Universitas Islam Negeri Sunan Kalijaga Yogyakarta \\ 1rina.rahmi23@gmail.com, ${ }^{2}$ aswatunhasanah23@gmail.com, \\ ${ }^{3}$ septika28@gmail.com
}

\begin{abstract}
This article aims to examine character education in primary age inclusion schools. Focus the discussion on research on the basic concepts of character education in inclusion schools, the process of character education planning in inclusion schools, how character education is implemented in inclusion schools, and how to monitor character education in inclusion schools. The approach used is a qualitative approach to library research. Data sources are obtained from books or journals relevant to this study. The data collection technique is to analyze character education in elementary age inclusion schools to obtain data from literature sources. Data analysis was conducted by examining the concept of character education in basic age inclusion schools using reference materials. The results of this study show that (1) character education planning in inclusion schools is carried out by meeting teacher work, socialization of all parties related to the school, and the preparation of a Learning Implementation Plan (RPP), (2) in the application of character education in inclusion schools through integrating in learning, self-development through school culture as habituation, as well as inclusion education (3) character education monitoring in inclusion schools including observation and direct mentoring, identify the obstacles that occur, make improvements from the constraints that occur, as well as measure the success of the implementation of character education programs. Inclusion education is done well because of the intertwining of cooperation and support from various parties to change the way of thinking in doing social tolerance and humanizing people.
\end{abstract}

Keywords: Character Education, Inclusion School.

Abstrak : Artikel ini bertujuan untuk mengkaji pendidikan karakter pada sekolah inklusi tingkat usia dasar. Fokus pembahasan pada penelitian pada konsep dasar pendidikan karakter di sekolah inklusi,proses perencanaan pendidikan karakter di sekolah inklusi, bagaimana penerapan pendidikan karakter di sekolah inklusi, serta

AR-RIAYAH : Jurnal Pendidikan Dasar vol. 4, no. 2, 2020

IAIN Curup - Bengkulu l p ISSN 2580-362X; e ISSN 2580-3611

http://journal.iaincurup.ac.id/index.php/JPD

DOI: $10.29240 /$ jpd.v4i2.1648 | p. $155-172$ 
bagaimana monitoring dari pendidikan karakter pada sekolah inklusi. Pendekatan yang digunakan yaitu pendekatan kualitatif metode studi kepustakaan (library research). Sumber data diperoleh dari buku atau jurnal yang relevan dengan penelitian ini.Adapun teknik pengumpulan datanya yaitu menganalisis pendidikan karakter pada sekolah inklusi tingkat usia dasar untuk mendapatkan data dari sumber-sumber literatur.Analisis data dilakukan dengan mengkaji konsep pendidikan karakter pada sekolah inklusi tingkat usia dasar dengan menggunakan bahan referensi. Hasil dari penelitian ini menunjukkan bahwa (1) perencanaan pendidikan karakter pada sekolah inklusi dilakukan dengan cara rapat kerja guru, sosialisasi semua pihak yang terkait dengan sekolah, dan penyusunan Rencana Pelaksanaan Pembelajaran (RPP), (2) dalam penerapan pendidikan karakter pada sekolah inklusi melalui mengintegrasikan dalam pembelajaran, pengembangan diri melalui budaya sekolah sebagai pembiasaan, serta pendidikan inklusi (3) monitoring pendidikan karakter pada sekolah inklusi meliputi pengamatan dan pembimbingan secara langsung, mengidentifikasi kendala-kendala yang terjadi, melakukan perbaikan dari kendalakendala yang terjadi, serta melakukan pengukuran keberhasilan dari pelaksanaan program pendidikan karakter. Pendidikan inklusi terlaksana dengan baik karena terjalinnya kerjasama dan dukungan dari berbagai pihak untuk mengubah cara berpikir dalam melakukan toleransi sosial dan memanusiakan manusia.

Kata Kunci: Pendidikan Karakter, Sekolah Inklusi.

\section{PENDAHULUAN}

Pendidikan merupakan suatu proses yang dilakukan seseorang sehingga dapat mempengaruhi pertumbuhan dan perkembangannya untuk mencapai tujuan tertentu. Maka dari itu, pendidikan dapat dikatakan sebagai kebutuhan dasar setiap individu untuk menjamin keberlangsungan hidupnya. ${ }^{1}$ Suatu bangsa dapat dilihat perkembangan kemajuannya dari kualitas pendidikan. Oleh karenanya, pemerintah bertanggung jawab atas kemajuan bangsa ini. Pasal 31 undang-undang tahun 1945 telah mengatur bahwa pendidikan merupakan hak seluruh warga negara untuk mendapatkannya. Adapun prinsip penyelenggaraan pendidikan diatur dalam Undang-Undang Nomor 20 tahun 2003 tentang Sistem Pendidikan Nasional, yang menjelaskan bahwa pelaksanaan pendidikan dilakukan

1 Abdul Kadir and Dkk., Dasar-Dasar Pendidikan (Jakarta: Kencana Media Group, 2012), hal. 62. 
dengan demokratis, berkeadilan tanpa diskriminasi dengan mengutamakan norma keagamaan, hak-hak manusia, budaya, serta keberagaman bangsa. ${ }^{2}$

Setiap manusia mempunyai hak yang sama untuk dilindungi dan dihormati. Negara Indonesia sangat menjunjung tinggi harkat dan martabat manusia. Hal ini di atur dalam Pancasila dan Undang-Undang DasarNegara Republik Indonesia tahun 1945. Selanjutnya dalam Undang-Undang Nomor 20 tahun 2003 Pasal 5 ayat 2 menyatakan bahwa warga negara yang memiliki kelainan fisik, emosional, mental, intelektual, dan atau sosail berhak memperoleh pendidikan khusus. Oleh karena itu,perlindungan dan kemajuan terhadap hak warga negara khususnya anak-anak yang berkebutuhan khusus perlu diperhatikan. ${ }^{3}$

Dalam upaya menuntaskan program wajib belajar pendidikan 12 tahun, bangsa Indonesia masih memiliki tantangan berat. Diantaranya tantangan berkaitan dengan kesempatan dan partisipasi, serta tantangan perbaikan mutu pendidikan. Berkenaan dengan masalah tersebut, salah satu upaya pemerintah adalah menyelenggarakan pendidikan inklusi yang diyakini dapat meningkatkan daya jangkau dan kualitas proses belajar. Sesuai dengan kerangka Aksi UNESCO tahun 1994 dan pernyataan Salamanca pasal 2 yang menjelaskan bahwasanya sekolah reguler yang orientasinya inklusif adalah cara paling efektif dalam memerangi sikap diskriminatif sehingga mampu mewujudkan masyarakat yang mau terbuka, serta dapat membentuk masyarakat inklusif dalam menggapai pendidikan untuk semua. ${ }^{4}$ Dengan demikian, adanya pendidikan inklusif dapat meningkatkan efisiensi serta efektivitas biaya sistem pendidikan.

Pendidikan inklusi sendiri merupakan proses pendidikan dengan memberi penghargaan-penghargaan terhadap anak berkebutuhan khusus (ABK) melalui strategi penekanan pada keterpaduan secara penuh dan menghilangkan keterbatasan menggunakan prinsip pendidikan untuk siswa yang normal maupun siswa yang berkebutuhan khusus. ${ }^{5}$ Maka dari itu, setiap siswa yang mempunyai latar belakang berbeda dapat saling menghargai antara satu sama lainnya, baik berupa perbedaan sikap, suku, agama, etnis, dan perlakuan-perlakuan orang lain yang berbeda dari dirinya ${ }^{6}$ yang disebut dengan pendidikan karakter.

2 Kemendikbud, "Lampiran Undang-Undang Nomor 20 Tahun 2003 Tentang Sistem Pendidikan Nasional," n.d.

3 Deddy Kustawan and Budi Hermawan, Model Implementasi Pendidikan Inklusif Ramah Anak: Pedoman Penyelenggaraan Pendidikan Inklusi Di Sekolah Dasar Atau Madrasah Ibtidaiyah (Jakarta: Luxima Metro Media, 2013), hal. 1.

4 Muhammad Takdil Ilahi, Pendidikan Inklusif: Konsep Dan Aplikasi (Yogyakarta: ArRuzz Media, 2016), hal. 32.

5 Febri Yatmiko and Dkk, "Implementasi Pendidikan Karakter Anak Berkebutuhan Khusus," Journal Of Primary Education Vol.4 No.2 (2015): 78. Diakses pada 28 September 2020.

6 Pupuh Fathurrohman and Dkk, Pengembangan Pendidikan Karakter (Bandung: Refika Aditama, 2013), hal.19. 
Istilah karakter kerap dikenal dengan akhlak, sehingga dapat dikatakan bahwa karakter adalah nilai-nilai yang terdapat dalam kegiatan manusia saat melakukan interaksi dengan Penciptanya, dirinya sendiri, masyarakat dan lingkungan dengan berlandaskan norma agama, adat istiadat, budaya, dan hukum. ${ }^{7}$ Oleh karena itu, siswa yang memiliki karakter dengan kualitas yang baik berdasarkan norma yang telah disebutkan di atas dapat dijadikan sebagai hasil dari pengalaman belajar siswa.

Adapun nilai-nilai karakter yang dimaksud terdapat enam pilar yang terdiri dari respect, kepedulian, tanggung jawab, kepercayaan, kemauan berbagi, keadilan, dan kesadaran berwarganegara. ${ }^{8}$ Dengan adanya pendidikan inklusi, nilai-nilai karakter ini dapat diimplementasikan dalam lingkungan sekolah inklusi. Misalnya, siswa normal membantu siswa berkebutukan khusus sebagai bentuk kepeduliannya ketika melakukan aktivitas di luar kelas. Berdasarkan uraian diatas, penulis berusaha mengkaji pendidikan karater pada sekolah inklusi tingkat usia dasar. Fokus pembahasan pada penelitian pada konsep dasar pendidikan karakter di sekolah inklusi, proses perencanaan pendidikan karakter di sekolah inklusi, bagaimana penerapan pendidikan karakter di sekolah inklusi, serta bagaimana monitoring dari pendidikan karakter pada sekolah inklusi

\section{METODOLOGI PENELITIAN}

Artikel ini menggunakan pendekatan kualitatif, metode study pustaka (library research) memakai literatur-literatur dan buku sebagai objek utama. ${ }^{9}$ Kajian objeknya ialah buku dan sumber literasi terkait pendidikan karakter dan sekolah inklusi. Adapun teknik pengumpulan datanya menggunakan studi pustaka dimana sumber-sumber pustakanya meliputi buku, jurnal, dan lain sebagainya. ${ }^{10}$ Teknik pengumpulan data merupakan langkah strategis menganalisis pendidikan karakter pada sekolah inklusi tingkat usia dasar untuk mendapatkan data, maka sumber informasi dalam penelitian ini lebih ditekankan dari sumber-sumber literatur. Analisis data dilakukan dengan mengkaji konsep pendidikan karakter pada sekolah inklusi tingkat usia dasar. Oleh karenanya, verifikasi data dalam penelitian ini melalui bahan referensi. ${ }^{11}$

7 Fathurrohman and Dkk, hal.18.

8 Syamsul Kurniawan, Pendidikan Karakter: Konsepsi \& Implementasinya Secara Terpadu Di Lingkungan Keluarga, Sekolah, Perguruan Tinggi, \& Masyarakat (Yogyakarta: Ar-Ruzz Media, 2016), hal.41.

9 Sutrisno Hadi, Metodologi Research Jilid IV (Yogyakarta: Andi Offets, 1995), hal..3. hal. 5

10 Mestika Zed, Metode Penelitian Kepustakaan (Jakarta: Yayasan Obor Indonesia, 2004),

11 Andi Prastowo, Pembelajaran Konstruksivistik-Scientific Untuk Pendidikan Agama Di Sekolah/Madrasah: Teori, Aplikasi, Dan Riset Terkait (Jakarta: Rajawali Press, 2014), hal. 273. 


\section{HASIL DAN PEMBAHASAN}

\section{Perencanaan Pendidikan Karakter Pada Sekolah Inklusi Tingkat Usia Dasar}

1. Konsep Dasar Pendidikan Karakter

Pendidikan karakter ialah penerapan aktivitas dan tertib pada pengambilan keputusan terhadap interaksi dengan Tuhan maupun sesama manusia dalam proses mengembangkan nilai-nilai moral peserta didik. ${ }^{12}$ Pengembangan nilai-nilai moral peserta didik tidak terlepas dari bimbangan guru. Karakter dibentuk dari tiga macam yang terdiri dari pengetahuan, perasaan dan perilaku moral. ${ }^{13}$ Pengetahuan moral ialah kemampuan untuk mengetahui, memahami, mempertimbangkan moral yang dapat di terapkan dan di tinggalkan. Perasaan moral ialah melakukan tindakan moral atas kesalahan yang dilakukannya. Perilaku moral merupakan perilaku yang mengandung nilai-nilai di masyarakat sesuai dengan aturan yang dilaksanakan. ${ }^{14}$

Mengenai penjelasan di atas, uraian tersebut sejalan dengan tujuan pendidikan nasional berkaitan dengan nilai-nilai kemanusiaan yang harus dimiliki setiap warga negara. Untuk itu, nilai karakter dijabarkan dan diterapkan dalam konfigurasi psikologis dan sosiokultural sebagai berikut: ${ }^{15}$

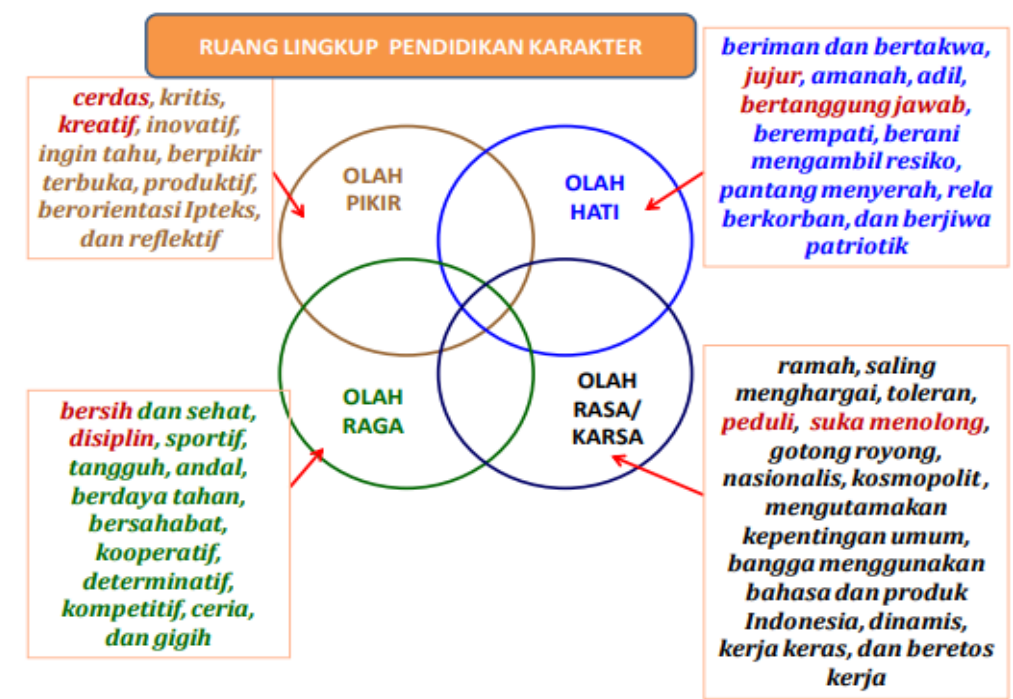

12 Rosdiatun, Model Implementasi Pendidikan Karakter (Gresik: Caremedia Communication, 2018), hal.. 21

13 Thomas Lickona, Pendidikan Karakter Panduan Mendidik Siswa Menjadi Pintar Dan Baik (Bandung: Nusa Media, 2008), hal.72.

14 Amirulloh Syarbini, Model Pendidikan Karakter Dalam Keluarga (Jakarta: Gramedia, 2014), hal.14. hal. 8-9.

15 Kementerian Pendidikan Nasional, Desain Induk Pendidikan Karakter (Jakarta, 2010), 
Gambar di atas menguraikan bahwa pendidikan karakter mempunyai 4 ruang lingkup yang terdiri dari olah pikir, olah hati, olah raga, dan olah rasa/karsa. ${ }^{16}$ Dimana setiap ruang lingkup tersebut telah diuraikan masingmasing contoh berkaitan dengan nilai kemanusiaan itu sendiri. Jadi, dapat ditarik kesimpulan bahwa bahwa konsep pendidikan karakter ialah pengembangan proses dari nilai-nilai moral yang dibentuk dari pengetahuan, perasaan, dan perilaku moral itu sendiri. Berkenaan dengan hal ini, dalam penelitiannya, Pamungkas menjelaskan bahwa ada beberapa pilar yang mrupakan modal dalam menyelenggarakan pendidikan inklusi, diantaranya: toleransi, semangat kebangsaan, bersahabat/komunikatif, peduli lingkungan dan peduli sosial. Untuk itu, pendidikan karakter tidak bisa dipisahkan dari pendidikan inklusi yang sarat dengan keberagaman. ${ }^{17}$ Dengan adanya penyelenggaraan sekolah inklusi, anak berkebutuhan khusus bisa dengan mudah mendapatkan akses pendidikan yang sama seperti anak normal pada umumnya.

2. Karakteristik Pendidikan Karakter

Karakter merupakan sifat dasar yang dimiliki setiap manusia. Karakter manusia bisa dirubah jika manusia berusaha merubah sifat yang buruk di dalam dirinya. Pada perkembangan manusia, terdapat dua faktor yang mempengaruhi terbentuknya karakter, diantaranya:

a. Faktor Luar (Internal-Endogen)

Awal anak terlahir di dunia, ia belum dapat mengendalikan diri sendiri atas keinginannya. Di usia dini anak mampu dibentuk karakternya dengan mananamkan sifat, sikap, dan tatanan sosial sesuai harapan orang tua. Di dalam diri anak juga memiliki sifat bawaan dari orang tuanya.

b. Faktor Eksogen/Nature (Faktor Lingkungan)

Terlahirnya manusia sudah tertanam bawaan sifat sejak lahir, meliputi nilai-nilai kekhilafan dan ketaqwaan. Dari sifat tersebut manusia masih memungkinkan untuk mengembangkan atau merubah dengan berbagai faktor diantaranya: dimensi pendidik dan dimensi sosial. ${ }^{18}$

16 Tim Kementerian Pendidikan Nasional, Panduan Pelaksanaan Pendidikan Karakter (Jakarta: Badan Penelitian dan Pengembangan Pusat Kurikulum dan Perbukuan, 2011), hal. 8.

17 Bayu Pamungkas, "Urgensi Pendidikan Karakter Untuk Mengoptimalkan Layanan Pendidikan Bagi Siswa Berkebutuhan Khusus Di Sekolah Inklusi," in Pendidikan, Etika Pendidikan: Pendidikan Karakter, Budi Pekerti, Dan Moral (Yogyakarta: Repository Universitas PGRI Yogyakarta, 2017), http://repository.upy.ac.id/id/eprint/1273, hal.. 5

18 Syaiful Islam, "Karakteristik Pendidikan Karakter; Menjawab Tantangan Multidimensional Melalui Implementasi Kurikulum 2013," Edureligia; Jurnal Pendidikan Agama Islam Vol.1 No.1 (2017), https://doi.org/10.33650/edureligia.v1i2.50. diakses Tanggal 28 September 2020. 
Nilai karakter yang mampu untuk dikembangkan ada 18 diantaranya religius, jujur, toleransi, disiplin, peduli, tanggung jawab dan lain sebagainya. Namun terlalu banyaknya nilai karakter, Menteri Pendidikan memilih nilai yang wajib dikembangkan untuk diimplementasikan pada anak-anak sebagai berikut: ${ }^{19}$

\begin{tabular}{lll} 
& OTAK & HATI \\
\hline Personal & Cerdas & Jujur \\
\hline Sosial & Tangguh & Peduli \\
\hline
\end{tabular}

Menyimpulkan bahwa karakteristik pendidikan karakter ialah sesuai harapan keluarga/orangtua untuk anak supaya terbentuk jadi pribadi yang baik dapat diubah melalui faktor internal-endogen yaitu dalam diri siswa intu sendiri dan faktor dari lingkungan.

c. Prinsip-Prinsip Pendidikan Karakter

Pendidikan karakter memiliki asas-asas yang mampu diterapkan untuk anak normal ataupun anak berkebutuhan khusus. Pendidikan di sekolah akan berjalan dengan baik apabila dalam penerapannya berlandaskan pada beberapa prinsip pendidikan karakter. Mengenai hal ini, Kementerian pendidikan nasional merekomendasikan beberapa prinsip demi terwujudnya pendidikan karakter yang efektif, diantaranya:

1) Landasan karakter diperkenalkan melalui nilai-nilai dasar etika.

2) Menentukan karakter secara luas agar meliputi pemikiran, perasaan dan perilaku.

3) Mempergunakan strategi yang nyata, aktif dan efektif untuk membentuk karakter.

4) Membuat komunitas sekolah guna menciptakan rasa saling peduli.

5) Siswa mendapatkan kesempatan untuk memperlihatkan perilaku yang baik.

6) Mempunyai lingkup terhadap kurikulum yang bermakna dan menantang siswa agar saling menghargai, membentuk karakter dan membantu satu sama lain agar berhasil. ${ }^{20}$

7) Membantu mengembangkan semangat/motivasi diri siswa.

19 Fathurrohman and Dkk, Pengembangan Pendidikan Karakter, hal. 20.

20 Asmani and Jamal Ma'mur, Buku Panduan Internalisasi Pendidikan Karakter Di Sekolah (Yogyakarta: Diva Press, 2012), hal. 56-57. 
8) Mengaktifkan semua pihak sekolah sebagai kelompok moral yang bertanggung jawab bagi pendidikan karakter dan berpegang teguh terhadap nilai yang ditetapkan.

9) Terbentuknya kelompok kepemimpinan moral dan mendapat dukungan penuh dalam membentuk ide pendidikan moral.

10) mengaktifkan berbagai pihak sebagai partner dalam membentuk karakter, dalam hal ini partner tesebut ialah keluarga dan masyarakat.

11) menilai karakter sekolah, fungsi pihak sekolah sebagai orang yang bertanggung jawab terhadap pendidikan karakter, dan perwujudan karakter positif dalam kehidupan siswa. ${ }^{21}$

Berbeda dengan prinsip yang disarankan kemendiknas, pendapat lain menyatakan bahwasanya program pendidikan karakter di sekolah harus dikembangkan dengan 4 prinsip berikut: ${ }^{22}$

1) Berkelanjutan (kontinuitas); artinya pendidikan karakter yang dilaksanakan pada satuan pendidikan mesti dilakukan secara berkelanjutan, hal ini dikarenakan untuk membentuk dan mengembangkan nilai-nilai karakter membutuhkan waktu yang lama, mulai dari proses input sampai menjadi output pada jenjang pendidikan tertentu.

2) Pendidikan karakter hendaknya dikembangkan melalui pembelajaran tematik (teritegasi semua mata pelajaran), maksudnya tidak hanya melalui mata pelajaran tertentu, melalui pengembangan diri, dan budaya sekolah tertentu. Untuk itu, pendidikan karakter dapat dikembangkan di setiap kegiatan siswa, mulia dari kegiatan kurikuler, ekstakurikuler bahkan melalui konseling.

3) Nilai karakter tidak diajarkan dalam bentuk pengetahuan pabila mata pelajarannya diintegrasikan, kecuali dalam bentuk pelajaran agama yang mengajarkan terkait doktrin, maka tetap diajarkan dengan proses, pengetahuan (knowing), dan melakukan (doing), hingga pada akhirnya menjadi sebuah kebiasaan (habit).

4) Proses pendidikan dilaksanakan secara active learning. Artinya proses pendidikan karakter dilaksanakan oleh siswa, bukan guru. Namun dalam hal ini guru mempunyai peran sebagai "tutwuri handayani" dalam setiap perilaku yang dianjurkan dalam agama.

Berkaitan dengan uraian di atas, ada beberapa hal yang harus dipenuhi terkait SDM guru dalam mengimplementasikan pendidikan karakter sesuai dengan prinsip-prinsip tersebut, diantarnya: mensinergikan ketiga komponen

21 Fathurrohman and Dkk, Pengembangan Pendidikan Karakter, hal. 145.

22 Lilis Rosita, "Peran Pendidikan Berbasis Karakter Dalam Pencapaian Tujuan Pembelajaran Di Sekolah,” JIPSI: Jurnal Ilmu Politik Dan Komunikasi Vol.8 No.1 (2018): 1-26, https://ojs.unikom.ac.id/index.php/jipsi/article/download/879/664. Diakses 20 November 2020. 
lembaga pendidikan (formal, informal, dan nonformal) dengan cara guru dan orangtua mendikskusikan terkait gejala-gejala anak yang mengarah pada hal yang negatif seperti ingin menyendiri, mengalami kejenuhan, kegelisahan, pertentangan sosial, kepekaan emosional, tidak percaya diri, timbul rasa tertarik pada lawan jenis, perasaan malu yanng berlebihan, suka menghayal dan lain sebagainya. Sehingga dengan adanya hubungan baik antara orang tua dan guru, gejala-gejala negatif di atas dapat di atasi dengan baik dan tepat. ${ }^{23}$ Selain itu, sebagaimana yang disebutkan Lickona, Schaps, dan Lewis ${ }^{24}$ serta Azra ${ }^{25}$ mengungkapkan bahwa dalm membentuk karakter SDM guru mempunyai beberapa peran berikut: 1) Guru terlibat aktif dalam proses pembelajaran, diskusi, dan menawarkan upaya-upaya membentuk karakter; 2) Sebagai rule models, guru bertanggung jawab untuk memberikan contoh/teladan bagi siswanya, mempunyai sikap terbuka dan senantiasa siap mendiskusikan mengenai nilai-nilai baik dengan siswanya;3) Memberikan gambaran kepada siswabahwa karakter itu dibentuk melalui kerjasama, dan berkecimpung dalam mengambil keputusan; 4) Merefleksikan sejumlah pertanyaan yang berhubungan dengan masalah moral yang terjadi dilingkungan dalam bentuk pertanyaan guna mengetahui perkembangan karakter siswa; 5) Mengklarifikasi nilai baik dan buruk dari setiap peristiwa yang terjadi. ${ }^{26}$

Mengenai hal ini pendapat lain menjelaskan bahwa bahwa dalam menerapkan pendidikan karakter pendidik dapat melakukan: 1) pembelajaran yang berpusat pada siswa (aktif); 2) lingkungan belajar yang kondusif; 3) pendidikan karakter diberikan secara jelas / tidak berbelit-belit, teartur dan berkelanjutan berdasarkan aspek knowing the good, loving the good, dan acting the good. Hal ini sejalan dengan apa yang dijelaskan Suyatno, bahwasanya bangsa Indonesia harusnya tidak hanya menyerukan terkait pentingnya pendidikan, akan tetapi ia harus mampu melaksanakan konsep dari pendidikan itu sendiri melalui pembinaan, pelatihan dan pemberdayaan SDM secara berkelanjutan dan merata; ${ }^{27}$ 4) memperhatikan keunikan setiap siswa dalam memilih metode pembelajaran berdasarkan kurikulum yang melibatkan 9 aspek kecerdasan manusia. ${ }^{28}$ Disamping itu, guru harus mampu melatih dan membentuk karakter

23 Suyanto and Hisyam Djihad, Pendidikan Di Indonesia Memasuki Milenium III: Refleksi Dan Reformasi (Yogyakarta: Sdicita Karya Nusa, 2000), hal. 186-187.

24 Thomas Lickona, Eric Schaps, and Catherine Lewis, "Eleven Principles of Effective Character Education: Character Education Partnership," 2007.

25 Azyurmadi Azra, Agama, Budaya, Dan Pendidikan Karakter Bangsa, 2006.

26 Suyatno, "Pengembangan Pendidikan Budaya Dan Karakter Bangsa," in Sarasehan Nasional (Jakarta: Kopertis Wilayah 3 DKI, 2010), hal. 7.

27 Suyatno.

28 Sofyan A Djalil and Ratna Megawangi, "Peningkkatan Mutu Pendidikan Di Acceh Melalui Implementasi Model Pendidikan Holistik Berbasis Karakter," in Makalab Orasi Ilmiah Pada Rapat Senant Terbuka Dalam Rangka Dies Natalis Ke 45 Universitas Syiah Kuala (Banda Aceh, 2006). 
anak melalui kebiasaan-kebiasaan sehingga terjadinya internalisasi karakter. ${ }^{29}$ Dengan demikian, keterssediaan sumber daya manusia yang berkaratker ialah kebutuhan yang sangat penting guna mempersiapkan tantangan global dan daya saing bangsa. Oleh karena itu, guru yang berperan sebagai tauladan bagi seluruh peserta didiknya harus mampu mencetak karakter SDM dengan pribadi yang kuat dan tangguh.

Dari uraian tersebut dapat dipahami bahwa peran guru dalam membentuk karakter siswa sangatlah besar. Sebagaimana yang dijelaskan sebelumnya, guru harus mampu memahami setiap keunikan siswa, oleh karena itu, penting bagi guru untuk mempelajari psikologi pendidikan dan sudah seharusnya menjadi suatu kebutuhan, hal ini disebabkann karena guru dituntut untuk memahami segala aspek perilaku siswanya agar dapat menjalankan tugas dan perannya dengan baik. Psikologi pendidikan mempelajari terkait pross manusia belajar dan berkembang, dan kerap terfokus pada kelompokkelompok tertentu seperti bakat siswa dan tertunduk pada anak berkebutuhan khusus sebagai penyandang cacat. $^{30}$ Untuk itu, guru yang mempunyai pengetahuan atau menguasai psikologis pendidikan akan berpengaruh pada proses belajar mengajar yang berdayaguna dan berhasil. Berkaitan dengan hal ini, setidaknya terdapat 10 kegiatan pendidikan yang membutuhkan prinsipprinsip pendidikan psikologi, yakni: seleksi penerimaan siswa baru, perencanaan pendidikan, penyususnan kurikulum yang disesuaikan dengn kebutuhan ABK (anak berkebutuhan khusus), ${ }^{31}$ penelitian kependidikan, administrasi kependidikan, pemilihan materi pembelajaran, interaksi belajar mengajar, memberikan layanan konsleling dan penyuluhan, metodologi mengajar, dan pengukuran/evaluasi. Oleh sebab itu, sosok guru yang berkompeten dan mampu mengimplementasikan prinnsip psikologis di atas ditinjau dari psikologi pendidikan ialah guru yang bertanggung jawab dalam menjalankan profesinya.

\section{Penerapan Pendidikan Karakter Pada Sekolah Inklusi Tingkat Usia dasar}

Sekolah inklusi bertujuan menyelenggarakan sekolah yang selaras dengan keadilan sosial yang dalam hal ini dapat menunjang prinsip normalitas, dan mempunyai banyak keuntungan lainnya. dimana sekolah ini beranggapan

29 Ary Ginanjar Agustian, "Membangun Sumber Daya Manusia Dengan Kesinergisan Antara Kecerdasan Spiritual, Emosional, Dan Intelektual," in Pidato Ilmiab Penganugerahan Gelar Kehormatan Doktor Ho\noris Causa Di Bidang Pendidikan Karakter (Yogyakarta: Universitas Negeri Yogyakarta, 2007).

30 Nofri Dodi, "Pentingnya Guru Untuk Mempelajari Psikologi Pendidikan," Nusantara (Jurnal Ilmu Pengetabuan Sosial) Vol. 1 No. (2016): 59-63, http://jurnal.umtapsel.ac.id/index.php/nusantara/article/view/93, hal. 60.

31 Tim Penelitian dan Pengembangan PusatKurikulum dan Perbukuan, Panduan Pelaksanaan Pendidikan Karakter (Jakarta: Badan Penelitian dan Pengembangan Pusat Kurikulum dan Perbukuan, 2011). 
bisa memberi manfaat bagi seluruh stakeholder termasuk bagi ABK itu sendiri. Disamping itu, hal ini juga memungkinkan kegiatan belajar bersama antara ABK dengan anak normal, serta ABK mendapat perlakuan yang sama layaknya anak-anak nornal lainnya. ${ }^{32}$ berkaitan dnegan hal ini, ternyata berdampak pada psikologis ABK itu sendiri, yakni: ABK mempunyai kesempatan terhadap pengembangan kepercayaan diri (self esteem). ${ }^{33}$ Self esteem ini sendiri mempunyai makna penilaian seseorang mengenai dirinya baik yang bersifat positif ataupun negatif. ${ }^{34}$

Dalam dunia pendidikan penyelenggaraan pendidikan karakter telah menjadi tanggung jawab bersama. Di lingkungan sekolah pendidikan karakter menjadi tugas baik kepala sekolah, guru, karyawan lembaga sekolah ataupun orang tua. Orang tua sangat berpengaruh dalam keterlibatannya terhadap pendidikan karakter anak. Oleh karena itu, kerjasama yang baik dari pihak sekolah dan keluarga/orangtua sangat dianjurkan untuk mencapai tujuan tersebut . Dengan demikian, proses penerapan pendidikan karakter perlu dilakukan secara bersama melalui berbagai cara berupa integrasi ke dalam pembelajaran, pengembangan diri, dan program pendidikan inklusi itu sendiri.

Penerapan pendidikan karakter pada sekolah inklusi dengan cara mengintegrasikan dalam pembelajaran ialah menanamkan nilai-nilai karakter antara anak reguler dengan anak berkebutuhan khusus (ABK) dalam pelaksanaan proses pembelajarannya terdapat lebih dari satu guru. Guru yang terdapat dalam kelas memiliki fungsi satu guru mengendalikan suasana kelas dan satu guru lainnya berfungsi membimbing dan memahamkan anak berkebutuhan khusus (ABK) dari apa yang disampaikan oleh guru kelas tersebut. Sesuai dengan buku panduan pelaksanaan pendidikan karakter oleh Kementerian Pendidikan Nasional menyatakan bahwa pengembangan diri ialah kerangka dari pengembangan pendidikan karakter siswa yang memuat pengembangan budaya sekolah sebagai pusat kegiatan belajar, dan kegiatan pengembangan diri pada sekolah inklusi dilakukan melalui proses pembiasaan pada siswa yang berupa kegiatan rutin, keteladaan, pengkodisian, kegiatan terprogram, dan ekstrakurikuler. ${ }^{35}$ Hal ini diperkuat oleh Sudrajat yang

32 IG.A.K. Wardani, Pengantar Pendidikan Luar Biasa (Jakarta: Universitas Terbuka, 2011), hal. 1-36.

33 M. Schmidt and B. Cagran, "Self-Concept Of Students In Inclusive Settings.," International Journal Of Special Education Vol. 23 No (2008).

34 Jamilah Chandra Pratiwi, "Sekolah Inklusi Untuk Anak Berkebutuhan Khusus: Tanggapan Terhadap Tantangan Kedepannya," in Prosiding Seminar Nasional Pendidikan: Meretas Sukses Publikasi Ilmiah Bidang Pendidikan Jumal Bereputasi (Surakarta: Universitas Sebelas Maret Surakarta dan ISPI Wilayah Jwa Tengah, 2015), hal. 239.

35 Yatmiko and Dkk, "Implementasi Pendidikan Karakter Anak Berkebutuhan Khusus." Hlm.81. 
mengemukakan bahwa cara penerapan pendidikan karakter disekolah terdiri dari 4 cara: 1) teaching; 2) modelling; 3) reinforcing (penguatan); 4) babituating. ${ }^{36}$

Berdasarkan uraian di atas, dalam menerapkan pendidikan karakter pada sekolah inklusi terdapat beberapa kelebihan dan juga kekurangan. Dimana kelebihannya menjadi faktor penunjang dan kekurangan tersebut dapat menjadi faktor penghambat bagi terselenggaranya implementasi pendidikan karakter disekolah inklusi. Untuk itu, berikut penulis uraikan faktor penunjang penerapan pendidikan karakter disekolah inklusi berasal dari SDM dalam hal ini ialah guru yang sudah berpengalaman, shadow (guru pendamping), struktur kepemimpinan sekolah, supervisi dan motivasi yang diberikan kepala sekolah, dan pemerintah kota. Sedangkan faktor penghambat dalam menerapkan pendidika karakter disekolah inklusi ialah terbatasnya atau bahkan belum tersedianya sarana dan prasarana yang lengkap dan memadai, ABK yang bersikap seperti siswa yang mengalami gangguan emosi, serta orang tua yang belum memahami terkait program sekolah sehingga mengkritisi kegiatan sekolah yang dilaksanakan. ${ }^{37}$

Adapun proses pembelajaran pendidikan karakter pada sekolah inklusi perlu memperhatikan lima hal sebagai berikut:

1. Membentuk dan menjaga kelompok belajar yang menerima keanekaragaman dan menghargai perbedaan, yang kemudian tercipta keterbukaan dan penghargaan yang baik tanpa menyudutkan satu sama lain.

2. Melakukan pembaharuan dalam penerapan kurikulum, guru melakukan pembaharuan dari pembelajaran kompetitif bergeser pembelajaran kooperatif yang melibatkan kerjasama antar siswa.

3. Mengupayakan pembelajaran secara interaktif, yakni model antar siswa saling bekerja sama, saling mengajar dan belajar, saling berpartisipasi secara aktif, serta bertanggung jawab terdahap pendidikannya sendiri maupun teman-temannya.

4. Mendorong guru untuk menghapus segala hambatan dalam proses pembelajaran, yaitu pengajaran secara tim maupun kolaborasi dengan berbagai cara mengukur keterampilan dan pengetahuan.

5. Melibatkan partisipasi aktif orang tua dalam proses perencanaan di sekolah maupun proses belajar di rumah. ${ }^{38}$

Berdasarkan paparan tersebut dapat dipahami bahwa dalam penerapan pendidikan karakter pada sekolah inklusi tingkat usia dasar dapat dilakukan

36 Ajat Sudrajat, “Mengapa Pendidikan Karakter,” Jurnal Pendidikan Karakter Vol.1 No.1 (2011): 47-59.

37 Mhd. Saleh, "Pendidikan Karakter Di Sekolah Inklusi: Studi Multi Situs Di SDN Sumbersari 1 Kota Malang Dan SD Muhammadiyah 04 Kota Batu” (UIN Maulana Malik Ibrahim Malang, 2018). Hlm. 1-196

38 J. David Smith, Sekolah Inklusif: Konsep dan Penerapan Pembelajaran (Bandung: Nuansa Cendekia, 2013), hal.398. 
dengan cara mengintegrasikan kedalam pembelajaran, pengembangan diri melalui pembiasaan dalam budaya sekolah, serta pendidikan inklusi. Melalui sekolah inklusi, pendidikan diharapkan mampu mengembangakan karakter sebagai berikut: 1) satu komunitas yang kohesif (melekat satu dengan yang lainnya); 2) menerima sertiap siswa (normal dan ABK) tanpa membedabedakan maupun mengolong-golongkan; 3) responsif terhadap kebutuhan siswa, jadi sekolah harus lebih peduli terhadap apa saja kebutuhan-kebutuhan siswanya tanpa pandang bulu. ${ }^{39}$ Lingkungan sekolah inklusi dapat kondusif bagi anak normal maupun anak berkebutuhan khusus (ABK) dengan merumuskan kurikulum yang diterima oleh semua pihak dengan indikator memungkinkan anak bereksplorasi, berinteraksi dengan berbagai pihak, sesuai minat dan bakat anak, serta melakukan penilaian secara merata. ${ }^{40}$

\section{Monitoring Pendidikan Karakter Pada Sekolah Inklusi Tingkat Usia Dasar}

Monitoring pendidikan karakter merupakan kegiatan program pembinaan melihat proses pelaksanaan memfokuskan pendidikan karakter berdasarkan tahapan ketentuan yang ditetapkan. Tujuan dari monitoring itu sendiri sebagai bahan pengembangan dan peningkatan kualitas dari program pendidikan karakter sehingga dapat melakukan upaya perbaikan dan penyempurnaan pada proses pendidikan karakter selanjutnya. Monitoring pendidikan karakter yang dilakukan pada sekolah inklusi tingkat usia dasar meliputi: 1) mengamati dan membina secara langsung pelaksanaan pendidikan karakter; 2) pengidentifikasi kendala-kendala yang terjadi dalam pelaksanaan pendidikan karakter; 3) melakukan perbaikan pelaksanaan pendidikan karakter atas analisis data kendala-kendala yang terjadi; 3) mengukur tingkat keberhasilan penerapan pendidikan karakter yang dilaksanakan. ${ }^{41}$

Pendidikan karakter yang diimplementasikan pada lembaga pendidikan merupakan suatu cara dalam melakukan pemanusiaan dan pembudayaan. Hal ini sebagai wujud dalam menciptakan lingkungan yang mampu menghargai antar sesama manusia, menghormati keutuhan dan keunikan ciptaan, dan membentuk pribadi berkompetensi intelektual serta moral yang seimbang sehingga tercipta masyarakat yang semakin manusiawi. ${ }^{42}$ Sama halnya pada sekolah inklusi yang memiliki keragaman perbedaan individual, diharapkan dengan diterapkannya pendidikan kerakter mampu menumbuhkan sikap kasih sayang, saling menghargai, percaya diri, dan kerjasama pada diri peserta didik.

39 Ilahi, Pendidikan Inklusif: Konsep Dan Aplikasi, hal. 32.

40 Weninda Ayu Retnoningtyas, "Pendidikan Karakter Dan Inklusi: Konsep Pendidikan Pada Anak Berkebutuhan Khusus," in Prosiding Konferensi Ilmiah Dasar (Madiun, 2018), hal.49.

41 Fathurrohman and Dkk, Pengembangan Pendidikan Karakter, hal. 195.

42 Erlis Riasti, "Implementasi Pendidikan Karakter Pada Kelas Inkluasi Di SD Negeri Widoro Kecamatan Pengasih Kabupaten Kulon Progo,” Jurnal Pendidikan Guru Sekolah Dasar Vol.9 No.4 (2015): 11. 
Melalui pendidikan karakter pada sekolah inklusi juga bertujuan agar peserta didik mampu memiliki sikap menghargai perbedaan baik di dalam pertemanan, lingkungan sekolah maupun masyarakat. Hal ini selaras dengan Hargio Santoso yang mengatakan bahwa pendidikan inklusi merupakan has asasi bagi setiap individu yang mampu meningkatkan torelansi sosial. ${ }^{43}$ Oleh karena itu, tujuan dari pelaksanaan pendidikan karakter pada sekolah inklusi tertanamnya sikap religius, kasih sayang, jujur, peduli, percaya diri, tanggung jawab, menghormati, menghargai perbedaan, empati, dan kerjasama.

Sikap - sikap yang diharapkan sebagai tujuan dari adanya pendidikan karakter di sekolah inklusi tentu saja perlu adanya tindak lanjut agar tidak tergerus oleh arus globalisasi dan perkembangan zaman. Beberapa tindak lanjut dalam pelaksanaan pendidikan karrakter di sekolah inklusi antara lain melalui keteladanan (modeling) dan penguatan (reinforcing). Melalui keteladaan dan memberikan contoh terhadap peserta didik salah satu cara yang dapat dilakukan oleh setiap orang namun sulit untuk dilakukan secara terus menerus, oleh karena itu pada saat peserta didik tingkat usia dasar yang memasuki tahap operasional konkret dimana dalam melakukan penguasaan pengetahuan membutuhkan contoh nyata maka perlu sosok yang dapat dilihat dan ditiru dalam kehidupan sehari-hari. ${ }^{44}$ Sehingga baik guru maupun orang dewasa lainnya di lingkungan sekolah menempatkan dirinya sebagai sumber contoh dari anak-anak.

Nilai-nilai karakter yang diberikan oleh guru perlu diperkuat oleh adanya penataan lingkungan dan kegiatan-kegiatan pendukung, serta pelibatan keluarga maupun masyarakat. Penguatan juga dapat dilakukan secara langsung oleh guru dengan perilaku sosial yang positif, memberi teguran bagi peserta didik yang berperilaku negatif, dan melakukan pendampingan personal untuk perilaku negatif yang wajib diperbaiki. Perilaku sosial positif dapat berupa pemberiaan penghargaan terhadap peserta didik berkarakter baik bisa melalui ungkapan verbal, penghargaan non verbal atau lainnya. ${ }^{45}$

Penataan lingkungan dapat dilakukan melalui pengarahan dan pemberian dukungan terciptanya suasana sekolah berkarakter terpuji dapat berupa pemasangan banner atau slogan sepanjang lingkungan sekolah. Visi misi sekolah yang mendukung pendidikan karakter, serta fasilitas, sarana prasarana yang nyaman dalam menanamkan nilia-nilai karakter juga perlu diperhatikan guna membentuk interaksi yang harmonis antar siswa baik yang

43 Santoso Hargio, Cara Memahami Dan Mendidik Anak Berkebutuban Khusus (Yogyakarta: Gosyen, 2012), hal.24.

44 Mumpuniarti, "Pembelajaran Nilai Keberagaman Dalam Pembentukan Karakter Siswa Di Sekolah Dasar Inklusi," Jurnal Pendidikan Karakter Vol.3 No.2 (2012): 154.

45 Novan Ardy W., Manajemen Pendidikan Karakter: Konsep Dan Implementasinya Di Sekolah (Yogyakarta: Pedagogia, 2012), hal.140. 
berkebutuhan khusus maupun yang normal. ${ }^{46}$ Pelibatan orang tua dan masyarakat sebagai langkah dalam memantau karakter peserta didik ketika di luar lingkungan sekolah karena karakter tidak dapat dinilai dalam satu waktu dan satu tempat perlu pengamatan dan identifikasi terus menuerus dalam kehidupan sehari-harinya. ${ }^{47}$ Sekolah dapat melakukan pemantauan karakter peserta didik dengan keluarga dan masyarakat secara periodik melalui komunikasi dan interaksi yang dibangun dengan baik.

Sebelumnya banyak masyarakat beranggapan bahwa anak berkebutuhan khusus ialah anak yang tidak berdaya dan perlu dikasihani, serta dikucilkan dalam lingkungannya sendiri. Tak jarang pula mereka mendapatkan perlakuan deskriminasi dari orang lain, bahkan untuk memperoleh haknya sebagai warga negara Indonesia berupa hak mendapatkan pendidikan pun mereka mengalami kesulitan. disatu sisi, sebagian sekolah reguler tidak mau menerima ABK sebagai siswa dengan berbagai alasan, namun disisi yang lain, ABK mengalami kendala untuk mendapatkan pendidikan di sekolah khusus yang disebabkan letaknya yang jauh dari tempat tinnggal mereka. Oleh sebab itu, banyak anak kebutuhan khusus yang tidak memperoleh pendidikan sebagai mana seharusnya.

Berdasarkan uraian di atas maka hemat penulis penerapan pendidikan karakter pada sekolah inklusi tingkat usia dasar penting laksanakan guna untuk menghindari perlakuan-perlakuan yang sangat tidak menguntungkan terhadap tumbuh kembanganya ABK. Dengan adanya sekolah inklusi, mereka memperoleh haknya sebagaimana yang disebutkan dalam pasal 31 UUD 1945 dan secara khsuus dijelaskan dalam pasal 5 terkait hak ABK terhadap jaminan kelangsungan pendidikannya dan memperoleh kesempatan yang sama serta mempunyai hak untuk mendapatkan pendidikan layanan khusus. Disamping itu, sekolah inklusi dapat menjadi wadah untuk mengembangkan karakter siswa secara keseluruhan (siswa normal dan $\mathrm{ABK}$ ) dan mengajarkan pada mereka tentang penerimaan terhadap teman-temannya yang berkebutuhan khusus akan terwujud, serta rasa peduli akan terbentuk dalam dii mereka berdasarkan keberagaman pada lingkungan belajarnya di sekolah inklusi. Bentuk kepedulian tersebut akan terlihat saat menyalurkan bantuan belajar kepada siswa lainnya yang berkebutuhan khusus. Hal ini dipertegas oleh Retnoningtyas dalam Prosiding Konferensi Ilmiah Dasar 2018 menyatakan bahwa dalam sekolah inklusi memiliki tingkat empati yang lebih tinggi, hal tersebut ditunjukkan dengan kesediaan anak-anak normal untuk membantu

46 Sudrajat, Mengapa Pendidikan Karakter., hal. 54-55.

47 Dharma Kesuma, Cepi Triatna, and Johar Permana, Pendidikan Karakter: Kajian Teori Dan Praktik Di Sekolah (Bandung: Remaja Rosdakarya, 2011), hal.141. 
anak-anak berkebutuhan khusus (ABK), sikap penuh pengertian, dan sikap toleransi. $^{48}$

\section{KESIMPULAN}

Dari pembahasan sebelumnya, maka dapat diambil kesimpulan bahwa penerapan pendidikan karakter disekolah inklusi tingkat usia dasar mempunyai sejumlah manfaat yang saling menguntungkan bagi siswa, terutama ABK terhadap pengembangan karakter siswa itu sendiri. Disamping mendapatkan haknya dalam memperoleh pendidikan, tidak ada lagi deskriminasi yang ia dapatkan di lingkungannya, justru malah sebaliknya. Teman-teman seusianya justru memberikan kepedulian dan menerima ABK layaknya anak normal lain pada umumnya. Selanjutnya, melalui pendidikan karakter disekolah inklusi mempunyai manfaat yang luar biasa bagi setiap siswa. Berkaian dengan hal ini, anak normal dan ABK mendapatkan perlakuan yang sama dan membentuk agar mempunyai karakter yang baik dan menambah nilai positif bagi masing-masing individu. Lebih lanjut, penerapan pendidikan inklusi di rancang dengan sebaik mungkin untuk menanam karakter-karakter positif tersebut hingga pada akhirnya membentuk sebuah kebiasaan yang diaplikasikan dalam kehidupan sehari-hari. Rancangan tersebut dimulai dari perencanaan, penerapan hingga membimbing secara langsung, sehingga memperoleh informasi yang akurat apa kendala dan bagaimana solusinya (monitoring), serta melakukan evaluasi terhadap program pendidikan karakter yang telah diterapkan.

\section{DAFTAR PUSTAKA}

Agustian, Ary Ginanjar. "Membangun Sumber Daya Manusia Dengan Kesinergisan Antara Kecerdasan Spiritual, Emosional, Dan Intelektual.” In Pidato Ilmiah Penganugerahan Gelar Kehormatan Doktor Honoris Causa Di Bidang Pendidikan Karakter. Yogyakarta: Universitas Negeri Yogyakarta, 2007.

Asmani, And Jamal Ma'mur. Buku Panduan Internalisasi Pendidikan Karakter Di Sekolah. Yogyakarta: Diva Press, 2012.

Azra, Azyurmadi. Agama, Budaya, Dan Pendidikan Karakter Bangsa, 2006.

Djalil, Sofyan A, And Ratna Megawangi. "Peningkkatan Mutu Pendidikan Di Acceh Melalui Implementasi Model Pendidikan Holistik Berbasis Karakter." In Makalah Orasi Ilmiah Pada Rapat Senant Terbuka Dalam Rangka Dies Natalis Ke 45 Universitas Syiah Kuala. Banda Aceh, 2006.

Dodi, Nofri. "Pentingnya Guru Untuk Mempelajari Psikologi Pendidikan." Nusantara (Jurnal Ilmu Pengetahuan Sosial) Vol. 1 No. (2016). Http://Jurnal.UmTapsel.Ac.Id/Index.Php/Nusantara/Article/View/93. Fathurrohman, Pupuh, And Dkk. Pengembangan Pendidikan Karakter. Bandung: Refika Aditama, 2013.

48 Retnoningtyas, Pendidikan Karakter Dan Inklusi: Konsep Pendidikan Pada Anak Berkebutuban Khusus, hal.48. 
Hadi, Sutrisno. Metodologi Research Jilid Iv. Yogyakarta: Andi Offets, 1995. Hargio, Santoso. Cara Memahami Dan Mendidik Anak Berkebutuban Khusus. Yogyakarta: Gosyen, 2012.

Ilahi, Muhammad Takdil. Pendidikan Inklusif: Konsep Dan Aplikasi. Yogyakarta: ArRuzz Media, 2016.

Islam, Syaiful. "Karakteristik Pendidikan Karakter; Menjawab Tantangan Multidimensional Melalui Implementasi Kurikulum 2013.” Edureligia; Jurnal Pendidikan Agama Islam Vol.1 No.1 (2017). Https://Doi.Org/10.33650/Edureligia.V1i2.50.

Kadir, Abdul, And Dkk. Dasar-Dasar Pendidikan. Jakarta: Kencana Media Group, 2012.

Kemendikbud. "Lampiran Undang-Undang Nomor 20 Tahun 2003 Tentang Sistem Pendidikan Nasional," N.D.

Kementerian Pendidikan Nasional. Desain Induk Pendidikan Karakter. Jakarta, 2010. Kesuma, Dharma, Cepi Triatna, And Johar Permana. Pendidikan Karakter: Kajian Teori Dan Praktik Di Sekolah. Bandung: Remaja Rosdakarya, 2011.

Kurniawan, Syamsul. Pendidikan Karakter: Konsepsi \& Implementasinya Secara Terpadu Di Lingkungan Keluarga, Sekolah, Perguruan Tinggi, \& Masyarakat. Yogyakarta: Ar-Ruzz Media, 2016.

Kustawan, Deddy, And Budi Hermawan. Model Implementasi Pendidikan Inklusif Ramah Anak: Pedoman Penyelenggaraan Pendidikan Inklusi Di Sekolah Dasar Atau Madrasab Ibtidaiyah. Jakarta: Luxima Metro Media, 2013.

Lickona, Thomas. Pendidikan Karakter Panduan Mendidik Siswa Menjadi Pintar Dan Baik. Bandung: Nusa Media, 2008.

Lickona, Thomas, Eric Schaps, And Catherine Lewis. "Eleven Principles Of Effective Character Education: Character Education Partnership,” 2007.

Mumpuniarti. "Pembelajaran Nilai Keberagaman Dalam Pembentukan Karakter Siswa Di Sekolah Dasar Inklusi." Jurnal Pendidikan Karakter Vol.3 No.2 (2012).

Pamungkas, Bayu. "Urgensi Pendidikan Karakter Untuk Mengoptimalkan Layanan Pendidikan Bagi Siswa Berkebutuhan Khusus Di Sekolah Inklusi.” In Pendidikan, Etika Pendidikan: Pendidikan Karakter, Budi Pekerti, Dan Moral. Yogyakarta: Repository Universitas Pgri Yogyakarta, 2017. Http://Repository.Upy.Ac.Id/Id/Eprint/1273.

Prastowo, Andi. Pembelajaran Konstruksivistik-Scientific Untuk Pendidikan Agama Di Sekolah/Madrasab: Teori, Aplikasi, Dan Riset Terkait. Jakarta: Rajawali Press, 2014.

Pratiwi, Jamilah Chandra. "Sekolah Inklusi Untuk Anak Berkebutuhan Khusus: Tanggapan Terhadap Tantangan Kedepannya." In Prosiding Seminar Nasional Pendidikan: Meretas Sukses Publikasi Ilmiah Bidang Pendidikan Jurnal Bereputasi, 239. Surakarta: Universitas Sebelas Maret Surakarta Dan Ispi Wilayah Jwa Tengah, 2015.

Retnoningtyas, Weninda Ayu. "Pendidikan Karakter Dan Inklusi: Konsep 
Pendidikan Pada Anak Berkebutuhan Khusus." In Prosiding Konferensi Ilmiah Dasar, 49. Madiun, 2018.

Riasti, Erlis. "Implementasi Pendidikan Karakter Pada Kelas Inkluasi Di Sd

Negeri Widoro Kecamatan Pengasih Kabupaten Kulon Progo." Jurnal Pendidikan Guru Sekolab Dasar Vol.9 No.4 (2015).

Rosdiatun. Model Implementasi Pendidikan Karakter. Gresik: Caremedia Communication, 2018.

Rosita, Lilis. "Peran Pendidikan Berbasis Karakter Dalam Pencapaian Tujuan Pembelajaran Di Sekolah." Jipsi: Jurnal Ilmu Politik Dan Komunikasi Vol.8 No.1(2018):Https://Ojs.Unikom.Ac.Id/Index.Php/Jipsi/Article/Downloa $\mathrm{d} / 879 / 664$.

Saleh, Mhd. "Pendidikan Karakter Di Sekolah Inklusi: Studi Multi Situs Di Sdn Sumbersari 1 Kota Malang Dan SD Muhammadiyah 04 Kota Batu." Uin Maulana Malik Ibrahim Malang, 2018.

Schmidt, M., And B. Cagran. "Self-Concept Of Students In Inclusive Settings." International Journal Of Special Education Vol. 23 No (2008).

Sudrajat, Ajat. "Mengapa Pendidikan Karakter." Jurnal Pendidikan Karakter Vol.1 No.1 (2011)

Suyanto, And Hisyam Djihad. Pendidikan Di Indonesia Memasuki Milenium Iii: Refleksi Dan Reformasi. Yogyakarta: Sdicita Karya Nusa, 2000.

Suyatno. "Pengembangan Pendidikan Budaya Dan Karakter Bangsa." In Sarasehan Nasional, 2. Jakarta: Kopertis Wilayah 3 Dki, 2010.

Syarbini, Amirulloh. Model Pendidikan Karakter Dalam Keluarga. Jakarta: Gramedia, 2014.

Tim Kementerian Pendidikan Nasional. Panduan Pelaksanaan Pendidikan Karakter. Jakarta: Badan Penelitian Dan Pengembangan Pusat Kurikulum Dan Perbukuan, 2011.

W., Novan Ardy. Manajemen Pendidikan Karakter: Konsep Dan Implementasinya Di Sekolah. Yogyakarta: Pedagogia, 2012.

Wardani, Ig.A.K. Pengantar Pendidikan Luar Biasa. Jakarta: Universitas Terbuka, 2011.

Yatmiko, Febri, And Dkk. "Implementasi Pendidikan Karakter Anak Berkebutuhan Khusus." Journal Of Primary Education Vol.4 No.2 (2015).

Zed, Mestika. Metode Penelitian Kepustakaan. Jakarta: Yayasan Obor Indonesia, 2004. 